Department of International Development

SLPTMD Working Paper Series

No. 003

Foreign Direct Investment, Absorptive Capacity and Regional Innovation Capabilities: Evidence from China

Xiaolan Fu 


\title{
Foreign Direct Investment, Absorptive Capacity and Regional Innovation Capabilities: Evidence from China
}

\author{
Xiaolan Fu \\ University of Oxford
}

\begin{abstract}
:
Innovation has widely been regarded as one of the main drivers of economic growth in the knowledge economy. This paper investigates the impact of foreign direct investment (FDI) on the development of regional innovation capabilities in developing countries using a panel dataset from China. We find that FDI can contribute significantly to the overall regional innovation capacity. The strength of this positive effect depends, however, on the availability of the absorptive capacity and the presence of innovation-complementary assets in the host region. The increased regional innovation and technological capability may contribute further to regional economic growth. FDI contributes not only to the outputs of the regional innovation system, but also to the productivity of innovation in the developing countries. Policy implications are discussed.
\end{abstract}




\section{Introduction}

Technological capabilities are a key component of competitiveness at national, regional or firm levels. The development of regional innovation capabilities has been of crucial importance for competitiveness building in both developed and developing countries. In the past decade there has been increasing research on the regional innovation system. It is argued that there is something distinctive and systemic about innovation as a localized phenomenon which cannot be predicted by the more familiar national innovation systems frameworks (Braczyk, Cooke and Heidenreich, 1998, and Meltcalfe, 1997). Although knowledge is a non-rival public production asset, which can generate positive externalities or spillovers to others (Nelson, 1959; Arrow, 1962, Griliches, 1979), knowledge spillovers are geographically localized (Jaffe, Trajtenberg and Henderson, 1993; Austreche and Feldman, 1996; Audretsch, 1998; Anselin, Varga and Acs, 1997; and Almeida and Kogut, 1997). Knowledge and information may flow more easily among agents located with the same area because of social bonds that foster reciprocal trust and frequent face-to-face contacts (Breschi and Lissoni, 2001). Therefore, there may be geographic boundaries to information flows or knowledge spillovers among the firms in an industry (Marshall, 1920 and Krugman, 1991). These spacially bounded knowledge spillovers allow companies operating nearby important knowledge sources to introduce innovations at a faster rate than rival firms located elsewhere. This is particularly the case for those 'tacit' knowledge, ie. highly contextual and difficult to codify, and is therefore more easily transmitted through face-to-face contacts and personal relationships. Therefore, innovation is more pronounced as a local phenomenon in a regional innovation system than in other wider eco-geographical systems. 
One of the important players in the regional innovation system is the multinational enterprises (MNEs) and their affiliates. MNEs are the major force conducting cuttingedge research and innovation. Multinational companies are often regarded to possess certain advantages which enable them to succeed in the global market. Their advantage, their firm-specific assets, are often of a technological nature. More than $80 \%$ of royalty payments for international technology transfers were made by affiliates to their parent companies (UNCTAD, 1997 and 2005). Therefore, openness of local economy and multinational enterprises (MNEs) located in the region may have a significant impact on regional innovation performance. The strength of the effect of FDI on regional innovation capacity may, however, depend on the absorptive capacity of the host regions. Although there has been some research on the role of absorptive capacity at the firm level, empirical studies of the role of absorptive capacity in the evolving regional innovation system in the developing countries has been rare.

In this paper, I will investigate the impact of FDI on regional innovation capabilities in China with special emphasis on the role of absorptive capacity and complementary assets in determining the strength of the assimilation and modification. This paper is organised as follows. Section II presents the theoretical framework for understanding relations between FDI, absorptive capacity and regional innovation performance. Section III discusses FDI and innovation in China and the innovation performance of foreign invested enterprises. Section IV presents empirical evidences. Section V concludes with some policy implications. 


\section{Foreign direct investment, absorptive capacity and regional innovation capabilities in developing countries: a theoretical framework}

The development of technological capabilities is the outcome of a complex interaction of inventive structure with human resources, technology efforts and institutional factors. It is the interplay of all these factors in particular country settings that determines at the regional level, how well the regions employ the resources and develop their technological capabilities (Lall, 1992). In other words, it is the efforts of the agents in a region, ie. business, government and the universities, and the strength of the linkages between these agents that determine the performance of a regional innovation system (Braczyk, Cooke and Heidenreich, 1998; Fu et al., 2006a).

Foreign direct investment contributes to regional innovation in four ways. First, R\&D activity and innovation generated by foreign firms and R\&D labs of MNEs increases the R\&D outputs in the region directly. Second, spillovers emanated from foreign innovation activities may affect the innovation performance in the region they locate. There are several channels for knowledge to spillover from foreign to local firms. These include knowledge transfers through the supply chain; skilled labour turnovers; and demonstration effects. Knowledge transfer via supply chain requires effective quality linkages between foreign firms and local suppliers and customers. When cross-regional labour mobility is low, it is likely that any benefits from MNEs will be local firms (Greenaway et al., 2002). Demonstration effects may also be local if firms only closely observe and imitate firms in the same region (Blomstrom and Kokko, 1998). There has been convincing evidence suggesting a productivity advantage of MNEs over domestic firms (eg. Girma, Greenawy and Wakelin, 2001). Empirical 
evidences on the actual extent of spillovers from MNEs to domestic firms are, however, mixed (Blomstrom and Kokko, 1998; Gorg and Greenaway, 2004).

Third, FDI may affect regional innovation capacity through competition effect. Market competition may also be a two-edged sword on innovation. Geroski (1990) argues that lack of competition in a market will give rise to inefficiency and result in sluggish innovative activity. On the other hand, the traditional Schumpeterians claim that monopoly power makes it easier for firms to appropriate the returns from innovation and thereby provides the incentive to invest in innovation (Cohen and Levin, 1989; Symeonidis, 2001). Foreign R\&D activities may also crowd out domestic innovation activities as they attracted the most talent researchers and compete in the markets of innovation products which threatens local firms, SMEs in particular (Aghion et al., 2005; Fu, 2004a and 2007). In the Chinese electronics industry, Hu and Jefferson (2002) find significant productivity depression rather than positive spillover effects of FDI on domestic firms.

Finally, in addition to greater R\&D investments by MNEs and their affiliates, FDI may contribute to regional innovation capabilities by advanced practices and experiences in innovation management and thereby greater efficiency in innovation. Innovation is not a simple linear transformation with basic science and other inputs at one end of a chain and commercialisation at the other (Hughes, 2003). Successful innovation requires more than brilliant scientists. It involves from top management to employees in its $R \& D$, finance, production and marketing divisions. It requires highquality decision-making, long-range planning, motivation and management techniques, coordination, and efficient $\mathrm{R} \& \mathrm{D}$, production and marketing. Therefore, 
innovation performance of a firm is determined not only by 'hard' factors such as R\&D manpower and R\&D investment, but also by certain 'soft' factors such as management practices and governance structures (Aghion and Tirole, 1994; Bessant et al., 1996; and Cosh, Fu and Hughes, 2004). MNEs are major participants in innovation and are more experienced in innovation management. They may contribute to local innovation system by transferring managerial know-how to local firms through spillover effects.

There are, however, two main conditions for significant spillovers from FDI: one is absorptive capacity of the local firms (Cohen and Levinthal, 1989; Girma, 2005); and second is the sufficient effective linkages generated between the foreign and domestic economic activities (Balasubramanayam, Salisu and Sapsford, 1996; Fu, 2004b). Absorptive capacity refers to the ability of an organisation or region to identify, assimilate and exploit knowledge from the environment (Cohen and Levinthal, 1989). Absorptive capacity is usually proxied by the technology gap between the foreign and the domestic firms, R\&D intensities of the local firms, or human capital embodied in local firms. Studies using the first approach find that spillovers are present when the technology gaps fare moderate (Kokko et al, 1996); smaller plants or plants with a low share of skilled workers in the workforce lack the necessary absorptive capacity to benefit from FDI. R\&D activities of organisations are regarded to have two faces (Aghion and Howitt, 1992 and 1998; and Griffith et al., 2003). One is the widely acknowledged knowledge creation function; another is its role in learning and promoting 'absorptive capacity' giving the fact that innovation is cumulative and path-dependent. It is argued that a certain level of R\&D intensity is needed before firms benefit from FDI-generated externalities. 
In addition to absorptive capacity, complementary assets (ingredients) may play an important role in forming the overall dynamic capabilities required to convert technological opportunities into innovative sales and competitive market advantage. (Teece, 1986; Teece, Pisano and Shuen, 1997; Brynjolfsson and Hitt, 2000; Cosh, Fu and Hughes, 2005; Hughes and Scott Morton, 2006; Cosh, Fu and Hughes, forthcoming). The introduction of substantially new or improved products requires parallel shifts in the strategy of organisations, the structure of organisations and practices in management. A region's acceptiveness to new idea, the strength of entrepreneurship, information and communication infrastructure as well as clusters of high-technology industries may all enhance a region's capability in assimilation of new idea and technology generated internally or transferred from external sources.

In summary, FDI impacts regional innovation capabilities in several ways. First, FDI may contribute to the overall regional innovation performance directly due to the greater innovation intensity in MNEs. Second, FDI may contribute to regional innovation performance through greater innovation efficiency in MNEs. Third, FDI may affect innovation capability of local indigenous firms through technological and managerial knowledge spillovers. The strength of the FDI effect on regional innovation capabilities depends upon the absorptive capacity of and the complementary assets in the domestic sector, the linkages between the foreign and the domestic sectors, and the technology content of the FDI.

\section{FDI and innovation in China}




\section{- $\quad$ FDI in China}

Since it launched the economic reforms and called for foreign capital participation in its economy in 1979, China has received a large part of international direct investment flows. China has become the second largest FDI recipient in the world, after the United States, and the largest host country among developing countries.

The phase started from the Spring of 1992, after Deng Xiaoping circuited China's southern coastal areas and SEZs, registered the fastest growth of FDI inflows into China. Since then, China adopted a new approach, which turned away from special regimes toward more nation-wide implementation of open policies for FDI. The inflows of FDI into China reached the peak level of US\$45 463 million in 1998. After a drop in 1999, mainly because of the impact of the Asian financial crisis and the rise of acquisition transactions in both OECD and non-OECD countries, FDI inflows into China picked up its fast growing trend and reached a historical peak of US60.63 billion (Figure 1).

This huge inflow of FDI is, however, highly concentrated geographically in the coastal region. By the year 1999, total FDI stock into the coastal provinces accounted for $88 \%$ of total FDI stock in China. FDI inflows into the coastal provinces accounted for 86 percent of total FDI inflow in China (Figure 2). This uneven distribution of FDI in China has its economic, policy and geographic attributes and generates uneven impact on regional competitive performance in China. As a result, the average FDI intensity measured by foreign assets in total industrial assets was $28 \%$ in the coastal region, which was 3 times higher than that in the inland region at only $7 \%$. In 
Guangdong, Fujian and Shanghai, nearly half of the net fixed industrial assets are foreign invested (Table 1).

\section{- Innovation}

As one of the important drivers of competitiveness, innovation effort and performance in China are not even across the regions. Again, there is a significant gap in innovation between the coastal and inland regions. In 2004, the coastal provinces accounted for 82 percent of China's total invention applications, 79 percent of the total sales of new products, and 73 percent of total industrial R\&D expenditure. The innovation activity in the coastal provinces is further concentrated in several provinces including Guangdong, Shanghai, Jiangsu, Shangdong and Zhejiang (Figures 3, 4, 5). Expenditure on acquisition of technology from abroad by the coastal region accounted for $67 \%$ of China's total expenditure on foreign technology acquisition in 2004, which was about twice of that in the inland region (Table 2).

\section{- Innovation by foreign firms}

Since late 1990s, with the increasing globalisation in innovation, R\&D activities of foreign firms in China has been increasing, at a faster pace than that of the domestic firms. The average annual growth of R\&D expenditure over the 1998 to 2004 period was 38 and 33 percent in foreign invested enterprises and Ethnic Chinese invested 
firms ${ }^{1}$, respectively. This is much higher than that in indigenous firms at 25 percent over the same time period (Table 3).

In 2004, the number of foreign firms was about one third of China's total number of enterprises. Although the $R \& D$ expenditure and $R \& D$ staff of the foreign firms accounted for only 27 percent and 18 percent of China's total industrial R\&D expenditure and $R \& D$ staff, innovation outputs by foreign firms in terms of percentage of total sales of new products and the percentage of invention patent application by foreign firms were both more than 40 percent. This suggests higher productivity in innovation and better innovation management in foreign firms than those in indigenous firms. The expenditure on acquisition of foreign technology by foreign firms accounted for nearly half of China's total expenditure on foreign technology acquisition, suggesting greater effort by foreign firms in acquiring advanced technology (Figure 6).

However, according to a recent report by Zhou (2006), most of the foreign R\&D labs in China are independent wholly foreign owned for better protection of intellectual property rights. More than 90 percent of these MNE's labs do not apply for patents to avoid disclosure of the technology know-how. About 80 percent of the foreign firms do not have any plan to collaborate with indigenous labs or firms or universities. Moreover, these foreign owned R\&D labs are again unevenly distributed geographically, with Beijing, Shanghai and Shenzhen accounted for nearly 84 percent of total foreign R\&D labs in China. A study by Fu et al. (2006b) based on 12 British enterprises operating in East Asia reveals that firms intend to use superior technology

\footnotetext{
${ }^{1}$ Ethnic Chinese invested firms refers to foreign firms which have owners from Hong Kong, Macao and Taiwan.
} 
rather than most advanced technology in their subsidiary or joint ventures in China. One of the main reasons is their concern about the poor intellectual property rights protection in China.

\section{FDI and innovation capacity: empirical evidence}

The econometric analysis of the impact of FDI on regional innovation capacity starts from a basic innovation production function as follows

$$
Y_{i, t}=\alpha+\beta R D S_{i, t-1}+\lambda R D P_{i, t-1}+\gamma H C_{i, t-1}+\delta F D I_{i, t-1}+\varepsilon
$$

where $\mathrm{Y}$ is innovation output, RDS is R\&D expenditure, RDP is the number of people involved in research and development activity, HC is human capital, FDI is FDI intensity measured by the ratio of net fixed assets of FIEs to total industrial net fixed assets in the region. $\varepsilon$ is the error term which has the normal property. All the variables are in logarithm. We use one year lagged values for all the explanatory variables. In other words, we assume that innovation production in a given year is reflected in the patents which are granted 1 year in the future. Another advantage in using one-year lag for the independent variables is that it removes the possible endogeneity between FDI and the dependent variable, number of patents, as FDI may choose to locate in regions that have high innovation capacity.

Here following Jaffe (1989) and Acs et al. (2002) we measure innovation output by number of patents granted to domestic applicants per 10 thousand population. Although patent number has its advantage, it also suffers from the low face validity problem that patents reflect little commercial success and value of new and renewed 
products (Acs and Audretsch, 1990; Kleintnecht, 1996). Investment in research and development $(\mathrm{R} \& \mathrm{D})$ is often found to be a significant determinant of innovation performance. Regions that invest more in $R \& D$ are more likely to innovate because R\&D directly creates new products and processes. Labour force skills, the availability of qualified scientists and engineers, particularly the qualified research staff directly involved in R\&D activities, are another widely recognized critical factor that contribute to firm innovation performance (Hoffman et al., 1998; Porter and Stern, 1999).

In order to capture the effects of absorptive capacity and complementary assets, we expend the model by including the interaction terms of FDI and absorptive capacity $(\mathrm{ABC})$ and FDI and complementary assets (CA) alternatively. According to the literature discussed earlier, absorptive capacity is measured in two ways alternatively: regional R\&D intensity (RDS) measured by R\&D spending to GDP ratio and labour force quality (HC) measured by percentage of population with 15 years schooling. They serve to enhance a region's capacity to recognise and absorb relevant external resources for innovation (Cohen and Levinthal, 1990). Complementary assets are also measured in three ways alternatively: (1) number of computers per thousand households (COMP) which may capture many innovative characteristics of a region, e.g. information infrastructure and acceptiveness to new idea; (2) the share of valueadded from high-technology industry in regional total value added (HITECS), which indicating the industry and technology structure in a region and the industry infrastructure to assimilate and develop the R\&D externalities from FDI; and (3) 
transaction value in technological markets ${ }^{2}$ (TECHMKT) which reflecting the development level and activeness of the institutions that facilitate the transfer of technology within a region. Equation (1) is thus extended to the following:

$$
\begin{aligned}
Y_{i, t}=\alpha & +\beta R D S_{i, t-1}+\lambda R D P_{i, t-1}+\gamma H C_{i, t-1}+\delta F D I_{i, t-1}+\theta A B C_{i, t-1} * F D I_{i, t-1} \\
& +C A_{i, t-1} * F D I_{i, t-1}+\varepsilon_{i, t}
\end{aligned}
$$

All the variables are in logarithm.

There are three types of patents, invention, utility model and external design. Invention is a new technical solution relate to a product, process or improvement thereof. Utility model refers to the practical and new technological proposals on the shape and structure of a product or the combination. External design involves a new design of shape, pattern, or combination or of color or aesthetic properties. Invention patents are regarded as major innovations. To obtain a patent for invention, an application must meet the requirements of "novelty, inventiveness and practical applicability". Usually, it takes about one to one and half years to process an invention patent application in China, but 6 months or even shorter for utility model and design patents (Cheung and Lin, 2004). Given the different novelty and importance of the three different types of patents, we run regression (2) using these three types of patent as the dependent variable alternatively in order to examine the impact of FDI on innovations of different degrees of novelty.

\footnotetext{
${ }^{2}$ Technological transactions include technology transfer, technology consultation, technical service, technical training, technology-equity share exchange, technology intermediation and various researchproduction co-operations
} 
The data used relates to a provincial level panel data set for the 31 provinces and municipality cities in China over the $1998-2004$ period. The data are collected from the China Statistical Yearbook and the Ministry of Science and Technology of China (MOST) online database. This study differs from some existing studies in that it uses the data from MOST for $R \& D$ expenditure and $R \& D$ staff rather than using the data of 'investment in innovation' published in the China Statistical Yearbook. The MOST data is more precise on $R \& D$ expenditure because 'investment in innovation' includes in addition to spending on research and development, also expenditure on renewal of fixed assets, capital construction, new site construction, as well as expenditure on the corresponding supplementary projects for production or welfare facilities and the related activities ${ }^{3}$. The MOST measurement of $R \& D$ is also better than using expenditure and staff on science and technology because, according to the definition

\footnotetext{
${ }^{3}$ It includes: (1) projects listed in the innovation plan of the current year of the central government and the local governments at various levels as well as the projects, though not listed in the innovation plan of the current year, but continued to be constructed in this year, using the investment listed in the plan of innovation of previous years and carried forward to this year; (2) projects of technological innovation or renewal of the original facilities, arranged both in the plan of innovation and in the plan of capital construction; extension projects (main workshops or a branch of the factory) with the newly increased production capacity (or project efficiency) not up to the standard of a large and medium-sized project; and the projects of moving the whole factory to a new site so as to meet the requirements of urban environmental protection or safe production; (3) projects of reconstruction or technological innovation with the total investment of 500,000 RMB yuan and over by the state-owned units, though listed neither in the plan of capital construction nor in the plan of innovation; the projects in the stateowned units of moving the whole factory to a new site so as to meet the requirements of urban environmental protection or safe production.
} 
given by MOST and SSB, science and technology includes the broad social science disciplines in addition to natural science and engineering disciplines.

Table 4 reports the estimation results of equation (2) on the impact of FDI on regional innovation capacity. The estimated coefficient of the FDI variable is positive and statistically significant at the 99 percent significance level. This fact suggests the significant contribution of FDI to regional innovation capacity. The magnitude for the estimated FDI coefficient in the base equation is 0.356 suggesting a one percent increase in FDI intensity increases regional patent output by 0.35 percent. These magnitudes are of the similar level of the $R \& D$ expenditure variable, some times even higher than that of the human capital variable.

The estimated coefficient of the two proxies of the absorptive capacity, RD intensity and labour force skills, bear the expected positive sign and are statistically significant at the 99 percent significance level as well. The estimated coefficients of the interaction terms between the absorptive variables and the FDI variable are positive and statistically significant as well. This evidence provides strong support to the proposition of the important role of absorptive capacity in assimilation of the knowledge spillovers from FDI.

We have three proxies to capture the complementary assets for innovation in the regions, number of computers per thousand household, the share of high-technology sector in regional total value-added, and the transaction value in technological market. The interaction terms between FDI and the first two complementary assets variables are positive and statistically significant as well, suggesting that FDI in regions with 
greater complementary assets, better information and communication infrastructure, greater acceptiveness to new ideas and a better developed cluster of high-technology sector will benefit to the innovation capacity of the local economy ${ }^{4}$. The estimated coefficient of the interaction variable between FDI and technological market transaction value bear the expected positive sign, but is not statistically significant. This maybe explained by the lack of foreign participation in the technological market as evidenced in a recent survey (Zhou, 2006), which we discussed in earlier section.

\section{FDI and regional innovation efficiency}

Statistical analysis to investigate the impact of FDI on regional innovation efficiency is in two steps. We first evaluate the innovation efficiency using the data envelopment analysis (DEA) which allows for multi-output and multi-input in the model. Second, we explore the role of foreign direct investment in the determination of regional innovation efficiency.

There are three main approaches to the measurement of efficiency: ratio analysis such as labour productivity and capital productivity, the normal econometric approach such as the Solow-type total factor productivity (TFP) index and the frontier approach, such as data envelopment analysis. Total factor productivity (TFP) provides a comprehensive guide to efficiency than partial productivity. It takes into account the contribution of factors, other than raw labour and capital, such as managerial skills

\footnotetext{
${ }^{4}$ The correlation coefficients between FDI intensity on one hand, and computer usage, share of hightechnology industry and technological market transaction values are as high as $0.57,0.54$ and 0.40 , respectively, and statistically significant at the $1 \%$ significance level. Inclusion of FDI and these complementary assets variables in the regression simultaneously raises significant multicolinearity problem. We, therefore, include FDI and the interaction terms only in the regress in addition to other variables of interest.
} 
and technical know-how. The conventional Solow-type total factor productivity defines TFP growth as the residual of output growth after the contribution of labour and capital inputs have been subtracted from total output growth. This method, however, attributes all the deviations from the expected output to TFP without taking into account measurement error. It is subject to several well-known assumptions: (1) the form of production function is known; (2) there are constant returns to scale; (3) there is optimising behaviour on the part of firms; and (4) there is neutral technical change. If these assumptions do not hold, TFP measurements will be biased (Coelli et al., 1998; Arcelus and Arocena, 2000).

The frontier approach evaluates a firm's efficiency against a measure of the best practice. There are two main methods for the estimation. One is a non-parametric programming approach, the Data Envelopment Analysis (DEA); another is a parametric production function approach, the Stochastic Frontier Analysis (SFA). In the DEA approach, a best-practice function is built empirically from observed inputs and outputs. The efficiency measure of a firm's innovation activity is defined by its position relative to the frontier of best performance established mathematically by the ratio of the weighted sum of outputs to the weighted sum of inputs (Charnes et al., 1978). The strength of the programming approach lies not only in its lack of parameterisation, but also in that no assumptions are made about the form of the production function. In addition, the programming approach allows us to estimate efficiency with multi-output and multi-input. This technique has a main shortcoming in that there is no provision for statistical noise, or measurement error, in the model (Greene, 1997; Norman and Stoker, 1991). The econometric production function approach, however, has the main advantage that measurement error can be minimised 
and hypotheses can be tested with statistical rigour; although it has the drawback that the production function is assumed to be known and to be homogeneous across firms.

Given the advantages and disadvantages of the different efficiency estimation approaches, we use the DEA approach in the estimation of the innovative efficiency because this method allows us to evaluate a firm's efficiency in innovation against best practice, and allows us to estimate efficiency with multi-output and multi-input.

In the DEA approach, for a sample of $\mathrm{n}$ firms, if $\mathrm{X}$ and $\mathrm{Y}$ are the observations on innovation inputs and outputs, assuming variable returns to scale, the firm's innovative efficiency score, $\theta$, is the solution to the linear program problem,

$$
\begin{aligned}
& \operatorname{Max}_{\theta, \lambda} \theta \\
& \text { st. } \quad \theta y_{i}+Y \lambda \geq 0 \\
& x_{i}-X \lambda \geq 0 \\
& \lambda_{i} \geq 0 \\
& \sum \lambda_{i}=1 \quad i=1, \ldots, n .
\end{aligned}
$$

where $\theta$ is a scalar and $\lambda$ is an $n \times 1$ vector of constants. The efficiency score ranges from 0 to 1 . If $\theta_{\mathrm{k}}=1$ and all slacks are zero, the kth firm is deemed to be technically efficient (Cooper et al., 2000).

In the analysis, since our major objective is to maximise innovation output, we concentrate on output-oriented efficiency, which reflects a firm's efficiency in producing maximum innovation output with given inputs, under constant returns to scale. Innovation output is measured by number of patents granted to each region. 
Given the differences in degrees of novelty across the three types of patents: invention, utility model and design, we include these three measures of innovation as outputs in our multi-output DEA model. Inputs in our models include the R\&D expenditure to GDP ratio and the total number of R\&D staff as a share of the total population. As invention patents are of higher degrees of novelty, we assume their importance is twice that of the utility models and design. Therefore, the weights restriction we use in the 3-outputs DEA model is as follows:

$$
Q_{\text {invention }}=2 q_{\text {utilitymodel }}=2 q_{\text {design }}
$$

The estimated regional innovation efficiency is then regressed on FDI intensity in each region. In the estimation of firm innovative efficiency, the efficiency scores have an upper bound of 1.0 and a lower bound of 0.0 , the ordinary least squares estimates would be inconsistent. Therefore, the regression model for technical efficiency is specified in form of the Tobit model as follows (Tobin, 1958; Fu and Balasubramanyam, 2003).

$$
I E=\left\{\begin{array}{cc}
\alpha+\beta X_{i}+\mu & \text { if } \alpha+\beta X_{i}+\mu<1 \\
1 & \text { otherwise }
\end{array}\right.
$$

where IE = innovative efficiency, and $X_{i}$ is a vector of explanatory and control variables including FDI intensity, labour force skills and industry structure in the region.

Figure 7 shows the distribution of the estimated regional innovation efficiency. Patterns revealed from this figure suggest that innovation efficiency of the Chinese regions has been increasing over time during the 2000 to 2005 period. Two observations form the regional innovation frontier. They are Shanghai in 2003 and 
2004. Other regions close to the frontier are the several coastal provinces and municipalities including Tianjin, Beijing, Zhejiang and Guangdong.

Table 5 reports the estimated results on the impact of FDI on regional innovation efficiency. The estimated coefficients of the FDI variable are positive and statistically significant at the 5\% significance level. The results are robust across different specifications, suggesting the significant positive impact of FDI on regional innovation efficiency. Regions with higher FDI intensity are more efficient in innovation. Human capital, measured by percentage of population with university degree has the largest impact on regional innovation efficiency. The estimated coefficient of the high-technology share variable bears an unexpected negative sign. This may be explained by the fact of heavy investment in $R \& D$ and large $R \& D$ personnel number in the domestic high-technology sector which have not been used efficiently.

\section{Innovation and regional economic growth}

Finally, we include the innovation output variable in a growth function in the light of the new growth theory, and estimate the impact of innovation on regional economic growth.

$$
y_{i t}=\alpha+\varphi t_{i t}+\beta l_{i t}+\not k_{i t}+\lambda x_{i t}+v_{i t}
$$

where $i$ and $t$ denote regions and time, respectively. The disturbance term, $v_{i t}$, varies across regions and time and has the usual properties. The dependent variable, $y_{i t}$, is the real growth rate of GDP; the explanatory variables are the number of patents granted, 
$t_{i t}$, the growth rate of labor, $l_{i t}$, the growth rate of the capital stock, $k_{i t}$, real growth rate of exports, $x_{i t}$, and $y_{i t-1}$, which is the one year lag of $y_{i t}$. Lower case denotes logarithm. We introduce exports into the production function explicitly for three reasons. First, the incentives associated with export orientation are likely to lead to higher total factor productivity because of economies of scale and competition effects. Second, exports are likely to alleviate serious foreign exchange constraints and thereby enable the country to import more advanced machinery and materials. Third, exports are likely to result in a higher rate of technological innovation and dynamic learning from abroad (Balasubramanyam et al., 1996).

We estimate equation (5) for all the regions in the country and for the coastal and inland region sub-groups separately. To examine the FDI-innovation-growth link in the two different regional groups, we also estimate equation (2) for the coastal and inland region sub-sample separately. The estimated results are reported in Table 6 . In the coastal region, FDI has been a significant contributor to regional innovation performance; and innovation again contributes significantly to output growth. The story in the inland region is, however, not the same. In the inland region, the estimated coefficient of the FDI variable though bearing the expected positive sign in the innovation function, it is not statistically significant. Again, the estimated coefficient of the innovation variable is not statistically significant although the sign is positive as expected. These facts suggest that FDI is not a significant driver of innovation capability in the inland region, nor does innovation to regional economic growth.

\section{Conclusions}


This paper has investigated the impact of FDI on regional innovation capabilities and efficiency in a fast growing developing country that received phenomenal amount of foreign direct investment. We find that FDI can contribute significantly to the overall regional innovation capacity. The strength of this positive effect depends, however, on the availability of the absorptive capacity and the presence of innovationcomplementary assets in the host region. In the coastal region of China, which possesses a pool of intelligent educated R\&D staff and skilled labor and hosts most of China's R\&D activities and top universities and research institutes, FDI has played a significant role in promoting regional innovation capacity as well as regional innovation efficiency over the 2000-2004 period. This increased regional innovation and technological capability contribute further to the fast regional economic growth in this region. However, in the inland provinces, they have not experienced such innovation-growth-promotion effect of FDI. The type and quality of FDI they attracted and the lack of absorptive capacity and complementary assets may all be blamed for this failure in the inland region.

Our attention to innovation has long been mistakenly placed on focusing on R\&D expenditure. R\&D spending is, however, only one of the important inputs of innovation. In many cases, huge $R \& D$ spending has been input into innovation activities but does not generate sufficient innovation output as we have expected. The productivity of innovation and the management of innovation are of crucial importance, especially for the developing countries whose resources for innovation are limited. This research shows that FDI contributes not only to the outputs of regional innovation system, but also to the productivity of innovation in the developing countries. 
The sample under study anchors in the time with increasing globalization of $R \& D$ activities. Findings from this study have important policy implications. First, globalization of R\&D may be another opportunity for the developing countries to catch up on the technology frontier. The quality and type of FDI are important for the significant innovation promotion effect of FDI. FDI into the coastal regions of China in the 21 century has been much different from the labour-intensity, export-oriented FDI in the early stage. Second, enhancement of local absorptive capacity has been crucial to the effective assimilation of the knowledge and technology spillovers from FDI. Finally the development of complementary assets in the local innovation system has also been crucial for greater success in assimilation and development of external knowledge. Therefore, there is a large role remains for government policies in promoting these necessary conditions for a successful FDI-assisted technological advancement.

Evidences from current study, however, provide little information on whether FDI has promoted the indigenous innovation capability of the developing countries. The current situation that most R\&D labs of MNEs are wholly-foreign-owned and that near 90 percent of them have no intention to collaborate with local firms raised concerns that these R\&D active foreign firms may remain as isolated innovation poles in the developing economy. Though they have increased the overall innovation inputs and outputs in the developing economy, their benefits to the technological capability building of the indigenous sector remain to be small. This may also give rise to another form of brain drain, which intelligent research staff has been lost from the domestic sector to the foreign sector though physically they stay in the country. Evidences from this study also suggest that the 
lack of effective protection to IPR has been a significant barrier preventing MNEs from introducing more advanced technology into China and investing more in innovation. Another important step for the governments of the developing countries is to strengthen the protection to intellectual property rights to attract more technology-intensive FDI and to encourage innovation. 


\section{References}

Acs, Z. S. and Audretsch, D. B. (1990). Innovation and Small Firms, Cambridge, MA: MIT Press.

Acs, Z. J., Anselin, Luc and Varga, Attila, 2002. 'Patents and innovation counts as measures of regional production of new knowledge', Research Policy, Vol. 31 Issue 7, p1069-86.

Aghion, P. and Tirole, J. (1994). 'The management of innovation'. The Quarterly Journal of Economics, 109, 4, 1185-1209.

Aghion, P., N. Bloom, R. Blundell, R. Griffith and P. Howitt (2005), Competition and innovation: An inverted U relationship, Quarterly Journal of Economics, May 2005, pp. 701-728.

Anselin, L., Varga, A. and and Acs, Z. (1997). 'Local geographic spillovers between university research and high technology innovations', Journal of urban economics, 42, 422-448.

Arrow, K. J. (1962), 'Economic welfare and the allocation of resources for invention', in R. R. Nelson (ed.), The Rate and Direction of Inventive Activity: Economic and Social Factors, Princeton, NJ: Princeton University Press for N.B.E.R., pp. 609-625.

Audretsch, D and Feldman, M., 1996. 'R\&D spillovers and the geography of innovation and production', American Economics Review, 86, 3, 630-40.

Balasubramanayam, V. N., Salisu, M. and Sapsford, D. (1996). 'Foreign direct investment and economic growth in EP and IS countries', Economic Journal, 106 (434), 92-105.

Bessant, J., Caffyn, S. and Gilbert, J. (1996). 'Learning to manage innovation'. Technology Analysis \& Strategic Management, 8, 1, 59-70. 
Blomstrom, M. and Kokko A. (1998) 'Multinational Corporations and Spillovers', Journal of Economic Surveys, 12(2): 1-31.

Braczyk, HJ., Cooke, P.; Heidenreich, M., 1998. Regional Innovation Systems: The role of governance in a globalized world. London; New York 2004 : Routledge.

Breschi, S. and Lissoni, F., 2001. 'Knowledge spillovers and local innovation systems: a critical survey', Industrial and Corporate Change, vol. 10, no. 4, 9751004.

Charnes, A., Cooper, W. W. and Rhodes, E. (1978). 'Measuring the Efficiency of Decision Making Units'. European Journal of Operational Research, 2, 6, 429444.

Cheung, K. and Lin, P., 2004. 'Spillover effects of FDI on innovation in China: evidence from the provincial data', China Economic Review, 15, 25-44.

Cohen, W. and Levin, R. C. (1989). 'Empirical studies of innovation and market structure'. in R. Schmalensee and R. D. Willig (eds.), Handbook of Industrial Organization: Vol . 2, Amsterdam: Elsevier Science Publishers.

Cooke, Philip, Uranga, Mikel Gomez and Etxebarria, Goio, 1997. 'Regional innovation systems: Institutional and organizational dimensions', Research Policy, Vol. 26 Issue 4/5, p475-91.

Cooper, W. W., Seiford, L. M. and Tone, K. (2000). Data Envelopment analysis: a comprehensive Text with Models, Applications, References and DEA-Solver Software, Boston/Dordrecht/ London: Kluwer Academic Publishers.

Cosh, A., Fu, X. and Hughes, A., 2004. 'How much does informality in management matter for SME innovation' the 35th Entrepreneurship, Innovation and Small 
Business (EISB) Conference, Barcelona, Spain, September 2005. Award winning paper, 2005 'European Best Paper Award'.

Cosh, A., Fu., X. and Hughes, A. 2005. 'Management characteristics, collaboration and innovative efficiency: evidence from UK survey data', Journal of Management Studies, forthcoming.

Cosh, A., Fu., X. and Hughes, A. forthcoming. 'Open innovation, complementary assets and regional innovation performance: evidence from UK survey data', Cambridge Journal of Economics.

Fu, X. and Balasubramanayam, V.N. (2003). 'Township and village enterprises in China'. Journal of Development Studies, 39, 4, 27-46.

Fu, X. 2004a. 'Limited Linkages from Growth Engines and Regional Disparities in China', Journal of Comparative Economics, 2004, vol 32, no. 1, 148-164.

Fu, X. 2004b. Exports, Foreign Direct Investment and Economic Development in China, Palgrave McMillan, London and New York.

Fu, X. 2007. 'Trade-cum-FDI, human capital inequality and the dual economy in China: the Signer perspective', Journal of Economic Change and Restructuring, forthcoming.

Fu, X., Cosh, A., Yang, Q. and Hughes, A., 2006a. 'World innovation frontier and the EU-US innovation gap'. Paper presented at the $9^{\text {th }}$ North America Workshop of Efficiency and Productivity Analysis, Stern Business School, New York University, New York, 2006.

Fu, X., Cosh, A. Hughes, A., De Hoyos, R. and Eisingerich, A., 2006b. 'The Experiences of UK Mid-corporate Companies in Emerging Asian Economies', UK Trade \& Investment, London. 2006 (URN 06/1137). 
Geroski, P. A. (1990). 'Innovation, technological opportunity, and market structure'. Oxford Economic Papers, 42, 3, 586-602.

Girma, S., 2005. 'Absorptive capacity and productivity spillovers from FDI: a threshold regression analysis', Oxford Bulletin of Economics and Statistics, 67, 3 281-306.

Girma, S., Greenaway and Wakelin, K., 2001. 'Who benefits from foreign direct investment in the UK?' Scottish Journal of Plitical Economy, 48, 19-33.

Görg, Holger and David Greenaway (2004), "Much ado about nothing? Do domestic firms really benefit from foreign direct investment?", World Bank Research Observer, Vol. 19, pp. 171-197.

Green, W. (1997). ‘Frontier production functions'. in M. H. Pesaran and P. Schimidt (eds.), Handbook of Applied econometrics, vol. II. Microeconomics, Oxford: Blackwell Publishers.

Greenaway, S. Upward, R. and Wright, P., 2002. 'Sectoral and geographic mobility of labour markets and structural adjustment, mimeo, University of Nottingham.

Griliches, Z. (1979). 'Issues in assessing the contribution of R\&D to productivity growth', Bell Journal of Economics, 10, 92-116.

Griliches, Z. (1992). 'The search for R\&D spillovers', Scandinavian Journal of Economics, 94, 29-47.

Grossman, Gene M. and Helpman, Elhanan, 1991. Innovation and Growth in The Global Economy. MIT press, Cambridge.

Hoffman, K., Parejo, M., Bessant, J. and Perren, L. (1998). 'Small firms, R\&D, technology and innovation in the UK: a literature review'. Technovation, 18, 1, 39-73. 
Hu, Albert and Jefferson, Gary, 2002. FDI impact and spillover: evidence from China's electronic and textile industries. World Economy, 38 (4), 1063-1076.

Hughes, A. (2003). 'Knowledge Transfer, Entrepreneurship and Economic Growth: Some Reflections and Implications for Policy in the Netherlands'. University of Cambridge Centre for Business Research Working Paper no.273.

Hughes, A. and Scott, M. 2007. 'Transforming Complementary assets into productivity' Stern Management Review.

Jaffe, A. (1989). 'Real effects of academic research', American Economic Review, 79, 957-70.

Jaffe, A., Trajtenberg, M. and Henderson, R. (1993) 'Geographic localization of knowledge spillovers as evidenced by patent citations', The Quarterly Journal of Economics, 108. 577-598.

Kokko, A., Tansini R. and Zejan M.C. (1996) 'Local Technological Capability and Productivity Spillovers from FDI in the Uruguayan Manufacturing Sector', Journal of Development Studies, 32(4) 602-611.

Krugman, Paul, 1991. Increasing returns and economic geography. Journal of Political Economy 99 (3), 483-499.

Lall, S., 1992. 'Technological capabilities and industrialization', World Development, $20(2), 165-186$.

Metcalfe, S. 1997. 'Technology systems and technology policy in an evolutionary framework, in Archibugi, D. and Michie, J. (Eds.) Technology, Globalisation and Economic Performance, Cambridge University Press, Cambridge.

Nelson, R. R. (1959), 'The simple economics of basic scientific research', Journal of Political Economy, 67: 297-306. 
Nelson, R. Institutions supporting technical advance in industry, American Economic Review, 76, 186-189 1986.

Norman, M. and Stoker, B. (1991). Data Envelopment Analysis: The Assessment of Performance, Chichester: John Wiley.

Porter, M. and Stern, S. (1999). The New Challenge to America's Prosperity: Findings from the Innovation Index. Council on Competitiveness, Washington, D.C., USA.

State Statistical Bureau of China (SSB), 2000-2001. China Statistical Yearbook. China Statistics Press, Beijing.

Symeonidis, G. (2001). 'Price competition, innovation and profitability: theory and UK evidence'. CEPR Discussion Paper No. 2816. Centre for Economic Policy research, London.

Teece, David J (1986), "Profiting from technological innovations," Research Policy, 15 (6), 285-306.

Teece, D. J., Pisano, G. and Shuen, A. (1997). ’Dynamic Capabilities and Strategic Management”. Strategic Management Journal, 18 (7): 509-533

Tobin, J. (1958). 'Estimation of relationship for limited dependent variables'. Econometrica, 26, 1, 24-36.

UNCTAD, 1997. World Investment Report: Globalisation of R\&D, United Nations, New York.

UNCTAD, 1997. World Investment Report: Transitional Corporations, Market Structure and Competition Policy, United Nations, New York.

Zhou, Y. (2006) 'Features and impacts of the internationalisation of R\&D by transnational corporations: China's case', in Globalisation of $R \& D$ and Developing Countries, UNCTAD, United Nations, New York and Geneva. 
Figure 1.

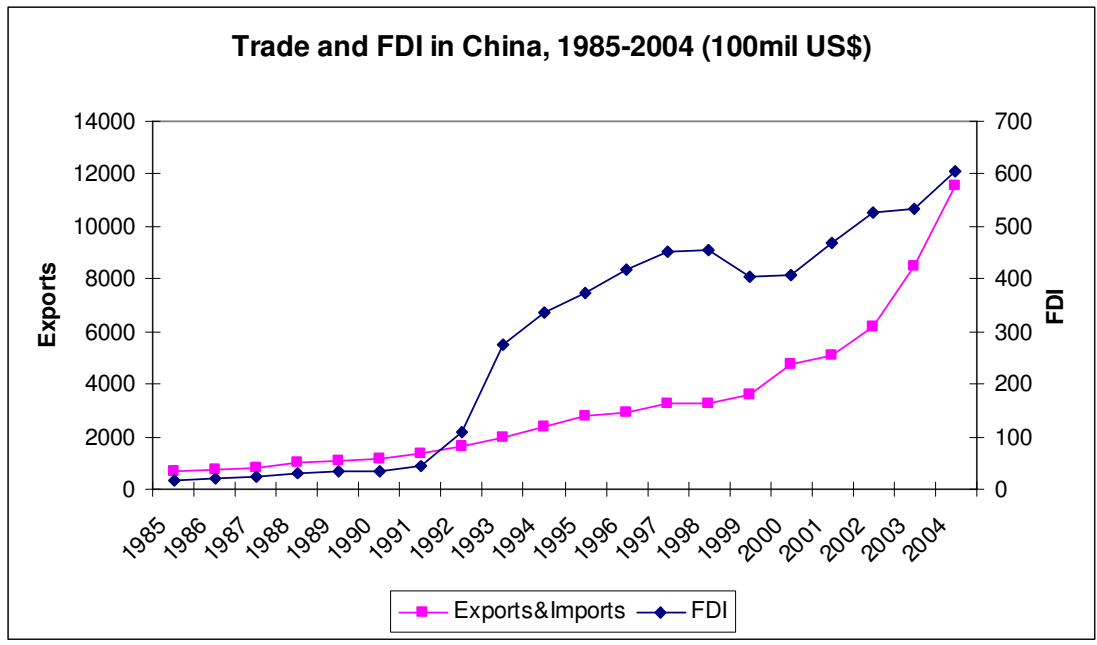

Source: Statistical Yearbook of China

Figure 2.

\section{Regional Distribution of FDI inflows 2003}

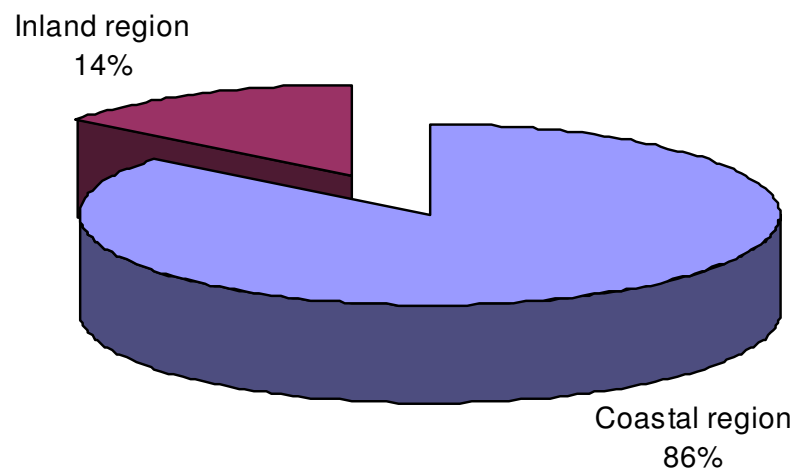

$\square$ Coastal region $\square$ Inland region

Source: Statistical Yearbook of China 
Figure 3.

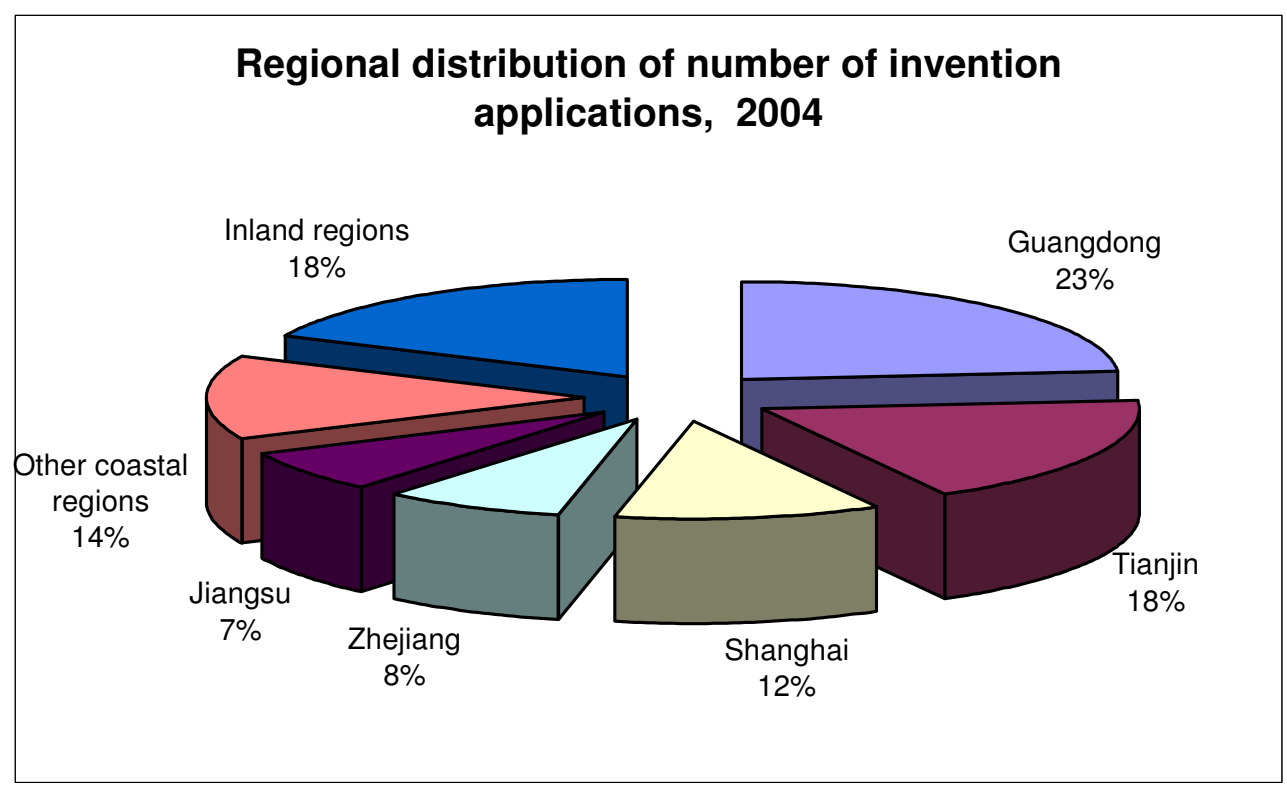

Source: First Economic Census of China, 2004.

Figure 4.

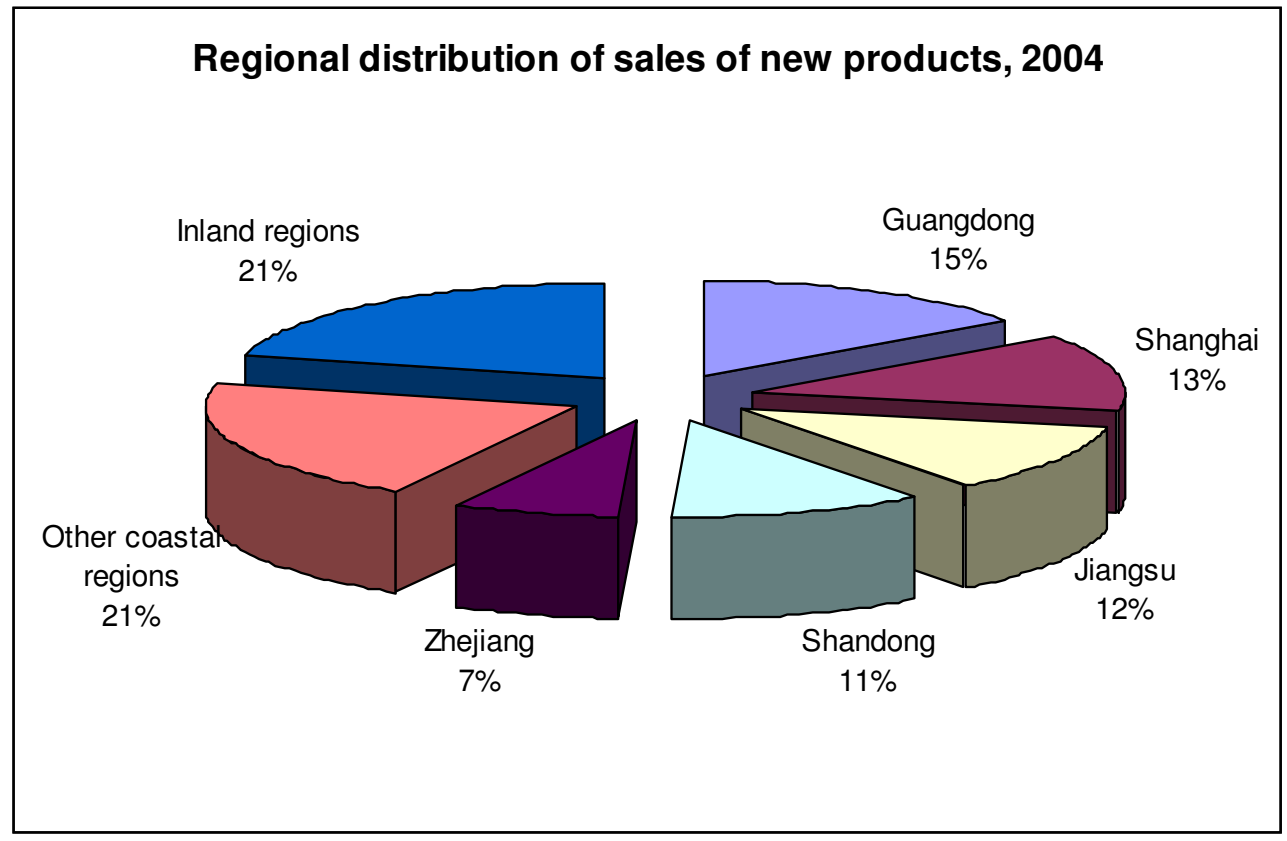

Source: First Economic Census of China, 2004. 
Figure 5.

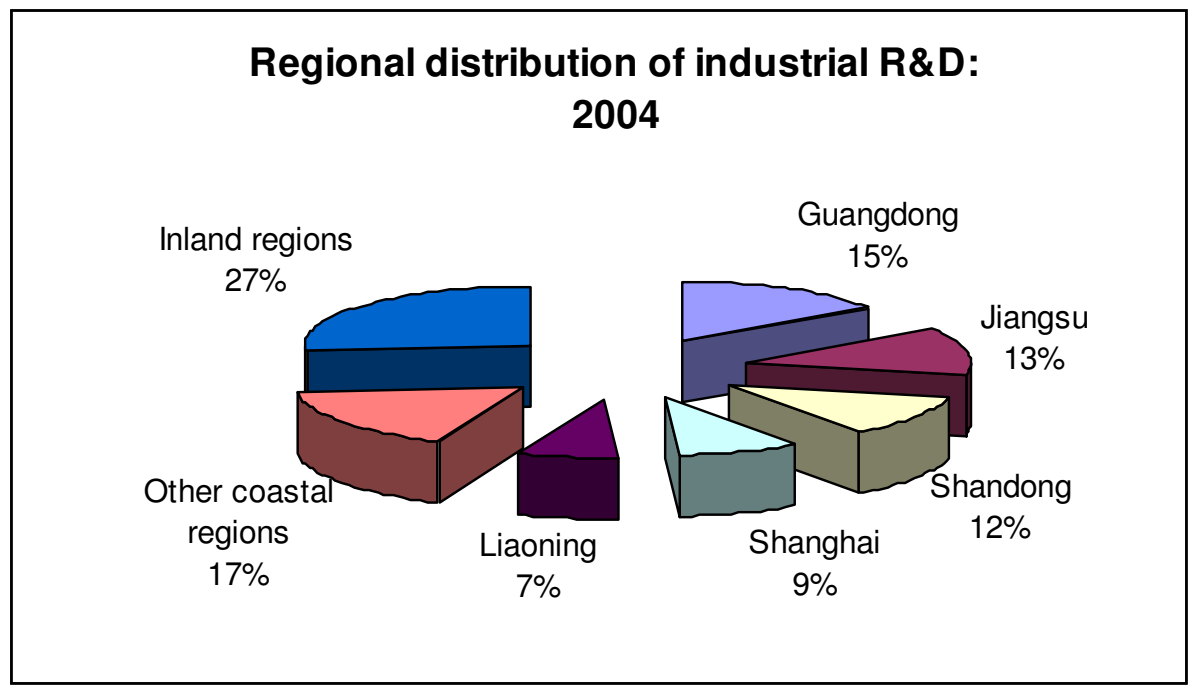

Source: First Economic Census of China, 2004. 
Figure 6.

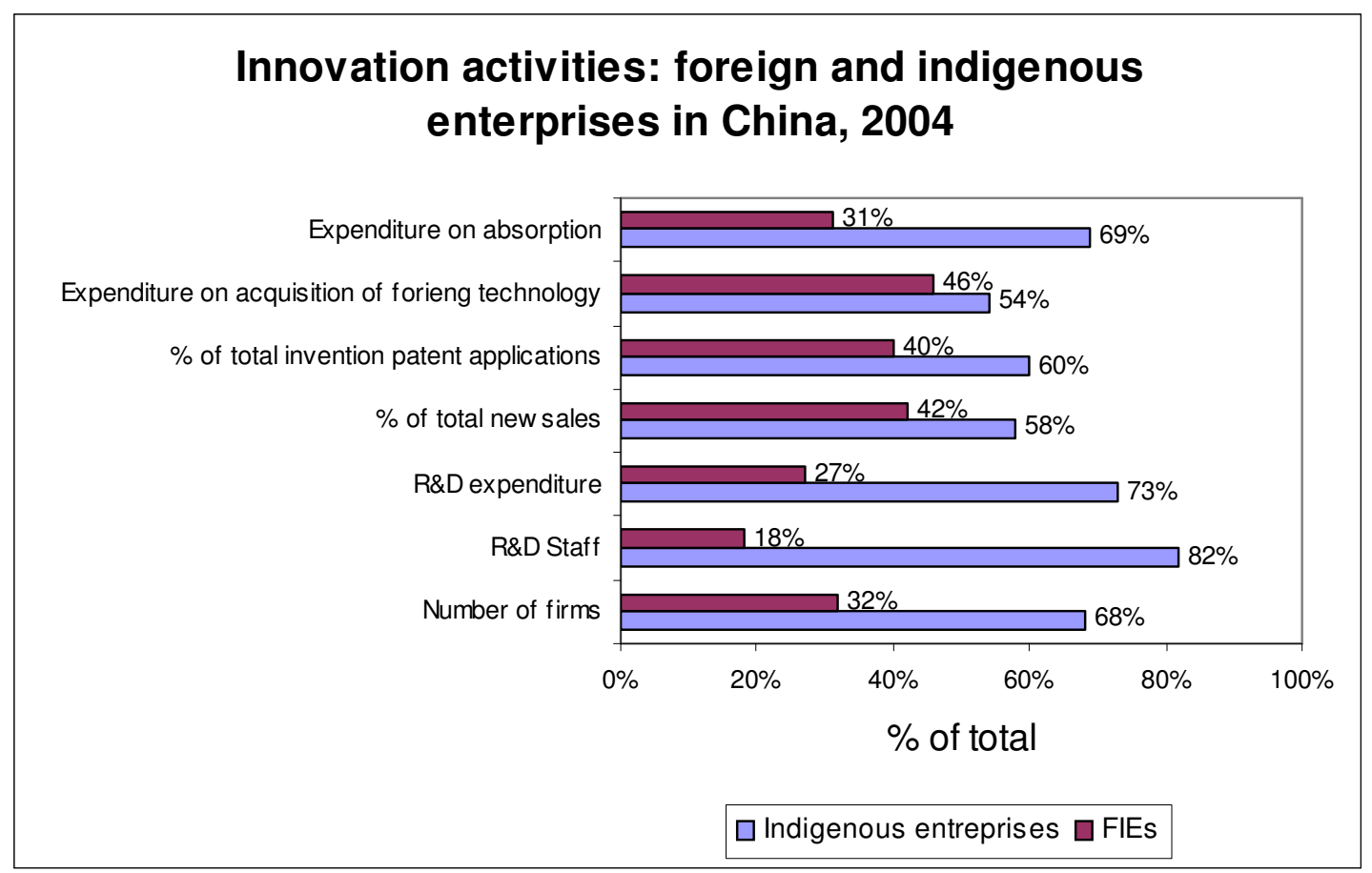

Source: First Economic Census of China, 2004. 
Figure 7.

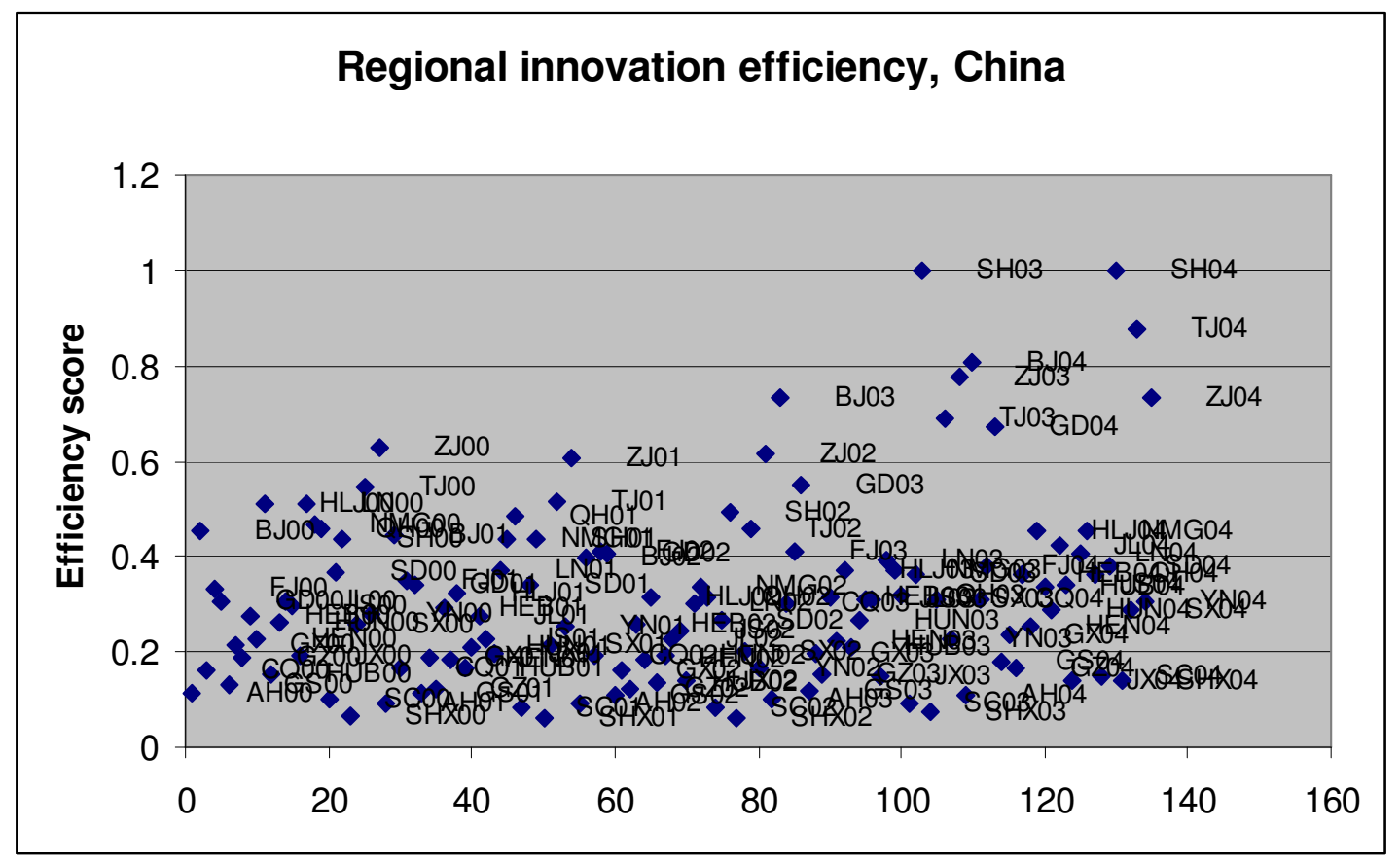


Table 1. FDI intensity: share of foreign assets in total industrial assets

\begin{tabular}{|c|c|c|c|}
\hline & 1999 & 2004 & 1999-2004 average \\
\hline Guangdong & $50 \%$ & $51 \%$ & $51 \%$ \\
\hline Fujian & $48 \%$ & $50 \%$ & $50 \%$ \\
\hline Shanghai & $40 \%$ & $49 \%$ & $44 \%$ \\
\hline Jiangsu & $28 \%$ & $37 \%$ & $32 \%$ \\
\hline Tianjin & $28 \%$ & $28 \%$ & $27 \%$ \\
\hline Beijing & $19 \%$ & $22 \%$ & $20 \%$ \\
\hline Zhejiang & $19 \%$ & $22 \%$ & $19 \%$ \\
\hline Liaoning & $16 \%$ & $16 \%$ & $15 \%$ \\
\hline Hainan & $19 \%$ & $14 \%$ & $15 \%$ \\
\hline Shandong & $13 \%$ & $16 \%$ & $14 \%$ \\
\hline Guangxi & $9 \%$ & $14 \%$ & $13 \%$ \\
\hline Hebei & $12 \%$ & $12 \%$ & $12 \%$ \\
\hline Coastal average & $25 \%$ & $28 \%$ & $26 \%$ \\
\hline Chongqing & $13 \%$ & $16 \%$ & $16 \%$ \\
\hline Anhui & $9 \%$ & $12 \%$ & $12 \%$ \\
\hline Jilin & $11 \%$ & $12 \%$ & $11 \%$ \\
\hline Hubei & $11 \%$ & $9 \%$ & $10 \%$ \\
\hline Jiangxi & $6 \%$ & $9 \%$ & $7 \%$ \\
\hline Henan & $8 \%$ & $7 \%$ & $7 \%$ \\
\hline Hunan & $4 \%$ & $8 \%$ & $6 \%$ \\
\hline Shaanxi & $6 \%$ & $4 \%$ & $6 \%$ \\
\hline Yunnan & $6 \%$ & $5 \%$ & $6 \%$ \\
\hline Sichuan & $4 \%$ & $6 \%$ & $5 \%$ \\
\hline Shanxi & $2 \%$ & $7 \%$ & $5 \%$ \\
\hline Ningxia & $4 \%$ & $8 \%$ & $5 \%$ \\
\hline Heilongjiang & $6 \%$ & $5 \%$ & $5 \%$ \\
\hline Inner Mongolia & $3 \%$ & $4 \%$ & $4 \%$ \\
\hline Gansu & $3 \%$ & $2 \%$ & $2 \%$ \\
\hline Guizhou & $2 \%$ & $3 \%$ & $2 \%$ \\
\hline Xinjiang & $2 \%$ & $1 \%$ & $1 \%$ \\
\hline Qinghai & $1 \%$ & $1 \%$ & $1 \%$ \\
\hline Tibet & $1 \%$ & NA & $1 \%$ \\
\hline Inland average & $5 \%$ & $7 \%$ & $6 \%$ \\
\hline
\end{tabular}

Source: Statistical Yearbook of China 
Table 2. Expenditure on technology acquisition, 2004

\begin{tabular}{|c|c|c|c|c|}
\hline Provinces & $\begin{array}{l}\text { Expenditure on } \\
\text { acquisition of } \\
\text { technology from } \\
\text { abroad }\end{array}$ & $\begin{array}{l}\text { Expenditure on } \\
\text { acquisition of } \\
\text { technology from } \\
\text { domestic sources }\end{array}$ & $\begin{array}{l}\text { Expenditure on } \\
\text { acquisition of } \\
\text { technology from } \\
\text { abroad } \\
\%\end{array}$ & $\begin{array}{c}\text { Expenditure on } \\
\text { acquisition } \\
\text { of technology from } \\
\text { domestic sources } \\
\%\end{array}$ \\
\hline Whole & 3679496 & 699192 & $100.0 \%$ & $100.0 \%$ \\
\hline Jiangsu & 549744 & 90289 & $14.9 \%$ & $12.9 \%$ \\
\hline Shanghai & 540190 & 33743 & $14.7 \%$ & $4.8 \%$ \\
\hline Beijing & 314287 & 2865 & $8.5 \%$ & $0.4 \%$ \\
\hline Guangdong & 258259 & 61465 & $7.0 \%$ & $8.8 \%$ \\
\hline Liaoning & 210968 & 14075 & $5.7 \%$ & $2.0 \%$ \\
\hline Tianjin & 163259 & 6578 & $4.4 \%$ & $0.9 \%$ \\
\hline Zhejiang & 151700 & 40682 & $4.1 \%$ & $5.8 \%$ \\
\hline Shandong & 138257 & 80177 & $3.8 \%$ & $11.5 \%$ \\
\hline Fujian & 64123 & 25842 & $1.7 \%$ & $3.7 \%$ \\
\hline Guangxi & 33388 & 11368 & $0.9 \%$ & $1.6 \%$ \\
\hline Hainan & 486 & 1108 & $0.0 \%$ & $0.2 \%$ \\
\hline Coastal region total & & & $65.9 \%$ & $52.7 \%$ \\
\hline Chongqin & 253162 & 36568 & $6.9 \%$ & $5.2 \%$ \\
\hline Hubei & 154054 & 38464 & $4.2 \%$ & $5.5 \%$ \\
\hline Hebei & 137388 & 29658 & $3.7 \%$ & $4.2 \%$ \\
\hline Henan & 127227 & 27226 & $3.5 \%$ & $3.9 \%$ \\
\hline Anhui & 85003 & 10095 & $2.3 \%$ & $1.4 \%$ \\
\hline Jilin & 84493 & 2695 & $2.3 \%$ & $0.4 \%$ \\
\hline Heilongjian & 74177 & 29977 & $2.0 \%$ & $4.3 \%$ \\
\hline Hunan & 66696 & 7769 & $1.8 \%$ & $1.1 \%$ \\
\hline Shaanxi & 60553 & 27010 & $1.6 \%$ & $3.9 \%$ \\
\hline Shanxi & 54788 & 18144 & $1.5 \%$ & $2.6 \%$ \\
\hline Jiangxi & 48822 & 24384 & $1.3 \%$ & $3.5 \%$ \\
\hline Sichuan & 47248 & 41492 & $1.3 \%$ & $5.9 \%$ \\
\hline Inner Mongolia & 20988 & 6157 & $0.6 \%$ & $0.9 \%$ \\
\hline Gansu & 16013 & 5579 & $0.4 \%$ & $0.8 \%$ \\
\hline Yunnan & 9627 & 15479 & $0.3 \%$ & $2.2 \%$ \\
\hline Ningxia & 9012 & 1850 & $0.2 \%$ & $0.3 \%$ \\
\hline Guizhou & 3966 & 4525 & $0.1 \%$ & $0.6 \%$ \\
\hline Xinjiang & 1529 & 3925 & $0.0 \%$ & $0.6 \%$ \\
\hline Qinghai & 90 & 4 & $0.0 \%$ & $0.0 \%$ \\
\hline Tibet & na & na & & \\
\hline Inland region total & & & $34.1 \%$ & $47.3 \%$ \\
\hline
\end{tabular}

Source: First Economic Census of China, 2004. 
Table 3.

Growth rate of R\&D expenditure

\begin{tabular}{l|ccccccc}
\hline & 1998 & 1999 & 2000 & 2001 & 2002 & 2003 & $\begin{array}{c}\text { average annual } \\
\text { change (1998-2004) }\end{array}$ \\
\hline Indigenous enterprises & $18 \%$ & $44 \%$ & $19 \%$ & $18 \%$ & $22 \%$ & $32 \%$ & $25 \%$ \\
FIEs by HK, M \& T & $50 \%$ & $23 \%$ & $12 \%$ & $25 \%$ & $27 \%$ & $59 \%$ & $33 \%$ \\
FIEs & $7 \%$ & $73 \%$ & $19 \%$ & $25 \%$ & $53 \%$ & $49 \%$ & $38 \%$ \\
\hline
\end{tabular}

Source: First Economic Census of China, 2004. 
Table 4. Impact of FDI on regional innovation capacity

\begin{tabular}{|c|c|c|c|c|c|c|c|c|c|c|c|c|}
\hline & \multicolumn{12}{|c|}{ Dependent variable: log (patents per thousand population) } \\
\hline & Coef & $p$-value & Coef & $p$-value & Coef & $p$-value & Coef & $p$-value & Coef & $p$-value & Coef & $p$-value \\
\hline$C$ & $1.309^{* * *}$ & 0.000 & $1.506^{\star * *}$ & 0.000 & $2.591^{* * *}$ & 0.000 & -0.663 & 0.118 & -0.277 & 0.564 & 0.145 & 0.689 \\
\hline LOG(RDGDP?(-1)) & $0.354^{* * *}$ & 0.002 & $0.690^{\star * *}$ & 0.000 & $0.243^{\star *}$ & 0.043 & 0.194 & 0.048 & 0.332 & 0.004 & 0.263 & 0.010 \\
\hline LOG(RDSTAF?(-1)) & $0.149^{*}$ & 0.058 & $0.147^{\star *}$ & 0.041 & $0.173^{\star *}$ & 0.025 & 0.191 & 0.003 & 0.137 & 0.075 & 0.022 & 0.741 \\
\hline $\mathrm{LOG}(\mathrm{HC} ?(-1))$ & $0.316^{\star \star *}$ & 0.000 & $0.304^{* * *}$ & 0.001 & $0.724^{\star * *}$ & 0.000 & 0.154 & 0.054 & 0.304 & 0.000 & 0.344 & 0.000 \\
\hline LOG(FDIS?(-1)) & $0.357^{\star \star \star}$ & 0.000 & $0.474^{\star \star \star}$ & 0.000 & $0.816^{\star \star \star}$ & 0.000 & -0.007 & 0.925 & -0.076 & 0.512 & 0.038 & 0.622 \\
\hline LOG(COMP?(-1)) & & & & & & & 0.536 & 0.000 & & & & \\
\hline LOG(HITECS?(-1)) & & & & & & & & & 0.697 & 0.000 & & \\
\hline LOG(TECHMKT?(-1)) & & & & & & & & & & & 481 & 0.000 \\
\hline LOG(FDIS?(-1))*LOG(RDGDP?(-1)) & & & $0.138^{\star * \star}$ & 0.008 & & & & & & & & \\
\hline LOG(FDIS?(-1))*LOG(HC?(-1)) & & & & & $0.134^{\star *}$ & 0.018 & & & & & & \\
\hline LOG(FDIS?(-1))*LOG(COMP?(-1)) & & & & & & & 0.153 & 0.000 & & & & \\
\hline LOG(FDIS?(-1))*LOG(HITECS?(-1)) & & & & & & & & & 0.206 & 0.000 & & \\
\hline LOG(FDIS?(-1))*LOG(TECHMKT?(-1)) & & & & & & & & & & & 131 & 0.000 \\
\hline LM & $258.21^{\star \star \star}$ & & $175.27^{\star * *}$ & & $247.74^{\star \star \star}$ & & $212.76^{\star *}$ & & $250.77^{\star *}$ & & & \\
\hline Hausman & 0.07 & & 2.18 & & 7.74 & & 6.53 & & 7.85 & & & \\
\hline Model & $\mathrm{RE}$ & . & $\mathrm{RE}$ & & $\mathrm{RE}$ & & $\mathrm{RE}$ & & RE & & & \\
\hline
\end{tabular}


Table 4. Impact of FDI on regional innovation capacity

\begin{tabular}{|c|c|c|c|c|c|c|c|c|c|c|c|c|}
\hline & \multicolumn{12}{|c|}{ Dependent variable: log (patents per thousand population) } \\
\hline & Coef & $p$-value & Coef & $p$-value & Coef & $p$-value & Coef & $p$-value & Coef & $p$-value & Coef & p-value \\
\hline C & $1.309^{* \star *}$ & 0.000 & $1.506^{\star \star \star}$ & 0.000 & $2.591^{* \star \star}$ & 0.000 & $1.383^{* * *}$ & 0.000 & $1.265^{\star \star \star}$ & 0.000 & $1.321^{* * *}$ & 0.000 \\
\hline LOG(RDGDP?(-1)) & $0.354^{* * *}$ & 0.002 & $0.690^{* * *}$ & 0.000 & $0.243^{* *}$ & 0.043 & $0.392^{* * *}$ & 0.001 & $0.403^{* * *}$ & 0.001 & $0.411^{* * *}$ & 0.000 \\
\hline LOG(RDSTAF?(-1)) & $0.149^{\star}$ & 0.058 & $0.147^{\star *}$ & 0.041 & $0.173^{\star *}$ & 0.025 & $0.157^{\star *}$ & 0.047 & $0.148^{\star}$ & 0.061 & 0.118 & 0.132 \\
\hline LOG(HC?(-1)) & $0.316^{* * *}$ & 0.000 & $0.304^{* * *}$ & 0.001 & $0.724^{* * *}$ & 0.000 & $0.337^{* * *}$ & 0.000 & $0.287^{* * *}$ & 0.001 & $0.334^{* * *}$ & 0.000 \\
\hline LOG(FDIS?(-1)) & $0.357^{\star \star *}$ & 0.000 & $0.474^{* * *}$ & 0.000 & $0.816^{\star \star *}$ & 0.000 & $0.310^{* \star *}$ & 0.000 & $0.299^{* * *}$ & 0.000 & $0.302^{* * *}$ & 0.000 \\
\hline LOG(FDIS?(-1))*LOG(RDGDP?(-1)) & & & $0.138^{* * *}$ & 0.008 & & & & & & & & \\
\hline LOG(FDIS?(-1))*LOG(HC?(-1)) & & & & & $0.134^{\star *}$ & 0.018 & & & & & & \\
\hline LOG(FDIS?(-1))*LOG(COMP?(-1)) & & & & & & & $0.020^{*}$ & 0.086 & & & & \\
\hline LOG(FDIS?(-1))*LOG(HITECS?(-1)) & & & & & & & & & $0.041^{* * *}$ & 0.007 & & \\
\hline LOG(FDIS?(-1))*LOG(TECHMKT?(-1)) & & & & & & & & & & & 0.010 & 0.291 \\
\hline LM & $258.21^{* * *}$ & & $175.27^{\star \star \star}$ & & $247.74^{\star * *}$ & & $212.76^{\star *}$ & & $250.77^{\star *}$ & & 268.82 & \\
\hline Hausman & 0.07 & & 2.18 & & 7.74 & & 6.53 & & 7.85 & & $32.18^{\star * *}$ & \\
\hline Model & RE & & RE & & $\mathrm{RE}$ & & $\mathrm{RE}$ & & $\mathrm{RE}$ & & FE & \\
\hline
\end{tabular}

Notes: ***Significance at 99\% level; ** significance at 95\% level; * significance at $90 \%$ significance level. 
Table 5. Impact of FDI on regional innovation efficiency

\begin{tabular}{|c|c|c|c|c|}
\hline \multicolumn{5}{|c|}{ Dependent Variable: LOG(IE) } \\
\hline Variable & Coefficient & Prob. & Coefficient & Prob. \\
\hline$C$ & $-0.963^{\star \star \star}$ & 0.000 & $1.481^{\star \star \star}$ & 0.001 \\
\hline LOG(FDIS?(-1)) & $0.157^{\star *}$ & 0.044 & $0.192^{\star \star}$ & 0.021 \\
\hline$L O G(H C ?(-1))$ & & & $0.596^{\star * *}$ & 0.000 \\
\hline LOG(HITECS?(-1)) & & & $-0.263^{\star *}$ & 0.012 \\
\hline \multicolumn{5}{|l|}{ Random Effects } \\
\hline Hausman statistics & 0.16 & & 0.05 & \\
\hline Adjusted R-squared & 0.14 & & 0.50 & \\
\hline
\end{tabular}


Table 6. The FDI-innovation-growth linkage in the coastal and inland regions

\begin{tabular}{|c|c|c|c|c|c|c|c|c|c|}
\hline \multicolumn{10}{|l|}{ Coastal } \\
\hline & \multicolumn{6}{|c|}{$\log (\operatorname{rgdp})$} & & \multicolumn{2}{|c|}{$\log ($ patent $)$} \\
\hline & Coef & p-value & Coef & $\mathrm{p}$-value & Coef & $\mathrm{p}$-value & & Coef & p-value \\
\hline LGL & -0.085 & 0.481 & -0.075 & 0.537 & -0.087 & 0.467 & FDIS & $2.834 * *$ & 0.018 \\
\hline LKY & $0.072 * * *$ & 0.004 & $0.095 * * *$ & 0.000 & $0.077 * * *$ & 0.002 & RDGDP & $0.513 * *$ & 0.023 \\
\hline LGREX & $0.097 * * *$ & 0.003 & & & $0.072 * *$ & 0.045 & $\mathrm{HC}$ & $6.176^{* *}$ & 0.010 \\
\hline LPATENT & & & $0.010 * * *$ & 0.008 & 0.006 & 0.119 & & & \\
\hline Constant & $0.166^{* * *}$ & 0.000 & $0.128 * * *$ & 0.002 & $0.125^{* * *}$ & 0.002 & Constant & $6.648^{* * * *}$ & 0.000 \\
\hline LM & 0.02 & & 0.48 & & 0 & & $\mathrm{LM}$ & 85.93 & \\
\hline \multirow[t]{2}{*}{ Hausman } & 5.9 & & 1.49 & & 5.01 & & Hausman & 6.54 & \\
\hline & $\mathrm{C}$ & & $\mathrm{C}$ & & $\mathrm{C}$ & & & $\mathrm{C}$ & \\
\hline \multicolumn{10}{|l|}{ Inland } \\
\hline & \multicolumn{6}{|c|}{$\log (\operatorname{rgdp})$} & & \multicolumn{2}{|c|}{$\log ($ patent $)$} \\
\hline & Coef & $\mathrm{p}$-value & Coef & $\mathrm{p}$-value & Coef & $\mathrm{p}$-value & & Coef & $\mathrm{p}$-value \\
\hline LGL & $-0.465^{*}$ & 0.050 & $-0.468 * *$ & 0.036 & $-0.469 * *$ & 0.037 & FDIS & 2.694 & 0.143 \\
\hline LKY & $0.055^{* * *}$ & 0.001 & $0.077 * * *$ & 0.000 & $0.078 * * *$ & 0.000 & RDGDP & 0.199 & 0.129 \\
\hline LGREX & 0.006 & 0.714 & & & -0.001 & 0.949 & $\mathrm{HC}$ & $4.231 *$ & 0.069 \\
\hline LPATENT & & & 0.006 & 0.154 & 0.006 & 0.155 & & & \\
\hline Constant & $0.138 * * *$ & 0.000 & $0.116 * * *$ & 0.000 & $0.116^{* * *}$ & 0.000 & Constant & $6.268 * * *$ & 0.000 \\
\hline LM & 4.55 & & $5.71 * *$ & & $5.71 * *$ & & LM & 133.36 & \\
\hline \multirow[t]{2}{*}{ Hausman } & 1.86 & & 3.08 & & 3.08 & & Hausman & 6.3 & \\
\hline & $\mathrm{C}$ & & $\mathrm{RE}$ & & $\mathrm{RE}$ & & & $\mathrm{C}$ & \\
\hline
\end{tabular}

Notes: ***Significance at 99\% level; ** significance at 95\% level; * significance at 90\% significance level. 